University of South Carolina

Scholar Commons

2006

\title{
In a Pig's Eye: Masculinity, Mastery, and the Returned Gaze of The Blithedale Romance
}

David Greven

University of South Carolina - Columbia

Follow this and additional works at: https://scholarcommons.sc.edu/engl_facpub

Part of the English Language and Literature Commons

\section{Publication Info}

Published in Studies in American Fiction, Volume 34, Issue 2, 2006, pages 131-159.

(c) Studies in American Fiction 2006, John Hopkins University Press

Greven, D. (2006). In a pig's eye: Masculinity, mastery, and the returned gaze of The Blithedale Romance. Studies in American Fiction, 34(2), 131-159.

http://dx.doi.org/10.1353/saf.2006.0006

This Article is brought to you by the English Language and Literatures, Department of at Scholar Commons. It has been accepted for inclusion in Faculty Publications by an authorized administrator of Scholar Commons. For more information, please contact digres@mailbox.sc.edu. 


\section{PROJECT MUSE}

\section{In a Pig's Eye: Masculinity, Mastery, and the Returned Gaze of The Blithedale Romance}

David Greven

Studies in American Fiction, Volume 34, Number 2, Autumn 2006, pp. 131-159 (Article)

Published by Johns Hopkins University Press DOI: 10.1353/saf.2006.0006

$\Rightarrow$ For additional information about this article http://muse.jhu.edu/journals/saf/summary/v034/34.2.greven.html 


\title{
IN A PIG'S EYE: \\ MASCULINITY, MASTERY, AND THE RETURNED GAZE OF THE BLITHEDALE ROMANCE
}

\author{
David Greven \\ Connecticut College
}

The young Ellen Langton stares at Fanshawe, the eponymous protagonist of Hawthorne's first novel, marvelling at his beauty; the Minister Hooper prevents anyone from seeing his face, hidden behind a black veil; Feathertop, believing he cuts a dashing figure, stares at himself in the mirror, discovering, to his horror, that he is merely the mirage of a man, a witch's illusion; Giovanni stares at lush, poisonous Beatrice Rappacini in her equally beautiful and deadly garden, little realizing that her father and Rappacini's own scientific rival, Baglioni, stares at Giovanni staring at her; Chillingworth triumphantly stares at the exposed flesh of sleeping, guilt-ridden Dimmesdale: these examples of the function of the gaze in Nathaniel Hawthorne's work metonymically symbolize numerous important issues that inform his oeuvre. Hawthorne's intensely, provocatively visual literary work invites cinematic comparisons. Joining numerous critiques in the field of film criticism, this essay challenges Laura Mulvey's well-known theory of the male gaze, using Hawthorne's work as an example of representation that complicates gendered subject positions vis-à-vis the gaze. ${ }^{1}$ In his work, Hawthorne makes it impossible to assign clear positions of dominance and submission. In so doing, he offers valuable contributions to our understanding of the construction and organization of gender and sexuality in the antebellum United States. By rendering male subjects as the objects as well as the wielders of the gaze, Hawthorne insists that we view men as possible objects of erotic contemplation, thereby beckoning queer and feminist analysis.

If the radical nature of Hawthorne's work lies, in part, in his insistence on rendering male figures the object of multiple gazes, Hawthorne's 1852 novel The Blithedale Romance poses a theoretical dilemma, since its protagonist, the cynical poet Miles Coverdale, clearly wields the gaze: one might even say his chief agenda is eluding the gaze of others by gazing at them first. In this essay, I examine the psychic costs of wielding the gaze, arguing that Hawthorne demonstrates the considerable potential personal risks involved in the avid desire to look, which he never treats as an act or symbol of power but, instead, as the very evidence of the debilitated fragility of the gazer. ${ }^{2}$ I 
am not arguing that Hawthorne depicts the phallic gazer as a victim who should be pitied for the patriarchal power he must embody and enact through gazing; this essay eschews any special pleading for the anxious condition of aggrieved American manhood. As Suzanne R. Stewart, in a study of late nineteenth-century masochism and manhood, writes, "The problem with so many postmodern theories of the subject is the elevation of the failure of subjectivity into a general condition of all subjectivity, a failure that is then celebrated as subversive." 3 The subversive energy of The Blithedale Romance lies in the manner whereby Hawthorne exposes Coverdale's act of seeming masculine dominance-wielding the gaze, voyeuristically devouring what he sees-as indicative of a hopelessly unsuccessful embodiment of male power. The novel can be read as a critique of developing antebellum forms and theories of American masculinity; an evocation of queer threats to it; and as a phobically defensive treatment of the issues of effeminacy that personally plagued Hawthorne.

Moreover, and more pressingly, I will argue that The Blithedale Romance provides a particular theorization of heteronormative masculinity's relationship to the male gaze. I compare constructions and theorizations of the voyeuristic gaze in Hawthorne, Freud, Lacan, and Alfred Hitchcock, artists and thinkers who all use the voyeuristic gaze as a means of both establishing and deconstructing normative models of patriarchal power. My chief focus is, however, Hawthorne, and in bringing in psychoanalytic and cinematic perspectives, I mean primarily to illuminate his work, particularly in the ways in which his ineluctable conservatism competes with a potential radicalismhis phobic demonizations with a heroic and embattled sensitivity. In this essay, I argue that the voyeuristic male gaze allows Hawthorne to spy on and confront normative forms of manhood and masculinity. ${ }^{4}$

\section{A Great Deal of Eye-Shot}

Unlike Fanshawe, Minister Hooper, Feathertop, and Dimmesdale, Miles Coverdale, Blithedale's cryptic first-person narrator, occupies the position of watcher, "the third man," or "the fourth side." 5 If characters like Fanshawe and Dimmesdale occupy the position of being the object of the desiring gaze-much like Endymion, the beautiful young man of Greek myth so beautiful that the moon goddess Selene insisted that Zeus cast a perpetual sleep over him so that she could forever gaze upon and caress him-Coverdale wields the gaze, if surreptitiously, almost as hidden a voyeuristic viewer as James Stewart's 
"Jeff" in Hitchcock's Rear Window (1954). ${ }^{6}$

Coverdale enjoys a "rare seclusion" in his "hermitage," a "leafy cave" high up in the branches of a pine tree. The "decay" of branches "lovingly strangled" by "vine" forms this "hollow chamber." Within his little bower, Coverdale counts "the innumerable clusters of my vine," and forereckons "the abundance of my vintage." Like Fanshawe, the protagonist of Hawthorne's first novel, he is a ruler in an autoerotic world of his own. "This hermitage," reveals Coverdale, "symbolized my individuality, and aided me in keeping it inviolate" (91-92). Coverdale's declaration firmly establishes that, while he fantasizes about Hollingsworth, Zenobia, and Priscilla, his first thoughts tend towards his own "vine" and "vintage," and the hermitage merely extrudes the interior, inviolate individuality into which Coverdale burrows. And from this vantage point, Coverdale "peeps," for his position is "loft enough to serve as an observatory," from which he can observe Hollingsworth, Priscilla, and the Blithedale goings-on. Coverdale transforms his inviolate sanctuary into a theater in which his scopophilic spectatorship has full voyeuristic reign and range-the self as Panopticon (92-93). ${ }^{8}$

Coverdale fetishistically gazes at those around him; the way he looks at Zenobia triggers her to call him on it: "I have been exposed to a great deal of eye-shot ... but never, I think, to precisely such glances as you are in the habit of favoring me with" (44). If, as in Mulvey's account, Coverdale spectacularizes Woman, Zenobia unflinchingly returns his gaze, a topic to which we will return. Coverdale's anguished appreciation of Hollingsworth's beauty - coming, as it does, along with a sense that Hollingsworth is neither terribly kind nor trustworthyappears to translate into onanistic fantasy with self-flagellating (shades of Dimmesdale) repercussions, "exemplifying the kind of error into which my mode of observation was calculated to lead me":

In my recollection of his dark and impressive countenance, the features grew more sternly prominent than the reality, duskier in their depth and shadow, and more lurid in their light. . . . On meeting him again, I was often filled with remorse, when his deep eyes beamed kindly on me... "He is a man after all!" thought I"his Maker's own truest image ... not that steel engine of the Devil's own contrivance, a philanthropic man!" But, in my woodwalks, and in my silent chamber, the dark face frowned at me again. (66)

Sophia Hawthorne knew very well that when Hawthorne referred to a solitary chamber, he evoked onanistic pleasure, one reason why she 
obliterated references to such "filthiness" in his writing. ${ }^{9}$ Like the onanist of antebellum health and sexual reformer Sylvester Graham's perfervid imaginings, Coverdale feverishly retreats into private "recollection" in his "silent," secret chamber, where reproduced images of Hollingsworth take on a lurid luster of almost explicitly onanistic and homoerotic fantasy, solidified even in negation by the phallicized quality of what Hollingsworth supposedly is not, a "steel engine."10 It is little wonder that when Coverdale sees Hollingsworth after his solitary imaginings, he feels remorse-even less wonder that this paragraph precedes both Coverdale's declaration that he finds Hollingsworth beautiful and the description of Blithedale as a Golden Age that promotes polyamorous amativeness, that authorizes "any individual, of either sex, to fall in love with any other, regardless of what would elsewhere be judged suitable and prudent" (67).

As I have elsewhere argued, this inviolate male in Hawthorne (and other authors' works) overlaps with the construction of the onanist in the theories of myriad antebellum sexual and health reformers such as Sylvester Graham, John Todd, and Mary Gove Nichols. ${ }^{11}$ In this essay, my focus will not be on onanism as a discursive category, but on Hawthorne's fusing of an onanistic with a voyeuristic persona in Coverdale, and the various effects such a fusion has on the novel. Recently, critics have linked Hawthorne's concerns in The Blithedale Romance to the science-fiction author and literary theorist Samuel Delaney's in Times Square Red, Times Square Blue, a study of peep shows, pornographic theaters, and social regulation in New York City. ${ }^{12}$ I take these claims to their logical conclusion, seeing Coverdale as an onanistic Peeping Tom in the ever-illuminated pornographic theater of the Blithedale community. If Coverdale is a Peeping Tom, it is a subject position that implies onanistic sensibility. Admiring the beauty of both men and women at Blithedale, Coverdale roams about this utopian space as onanistic voyeur, tourist of erotic possibilities..$^{13}$

Since Lacan reformulated Freud's theory of scopophilia-desiring looking, a form of looking that gives sexual power and pleasure-into the theoretical field of the gaze, the gaze itself has received so broad and complex a treatment in psychoanalytic theory and in film theory (psychoanalytically inflected and otherwise) that it would be impossible to attempt any kind of summarization of its history here. Focusing specifically on forms of the gaze most relevant to Blithedale - the voyeuristic and the returned gaze-we come to some suggestive points towards our fuller understanding of the gaze in Hawthorne.

The sadomasochistic quality of Coverdale's simultaneously anguished and merciless voyeurism makes Freud's treatment of voyeur- 
ism particularly illuminating. Archeologically excavating "the early history of the sexual instinct" in his Three Essays on the Theory of Sexuality, Freud observes that infantile sexuality "from the very first involves other people as sexual objects." Scopophilia, exhibitionism, and cruelty, linked "instincts," exist somewhat "independently" from erotogenic sexual activity, dominating the early lives of children, who, shame-free, exhibit a great "satisfaction" in exhibiting their own bodies before others. Onanistic children also develop an interest in the genitals of others, most often developing into "voyeurs, eager spectators of the processes of micturition and defecation," activities likeliest to satisfy eyes hungering for a glimpse of hidden genitals. After repression sets in, this desire to see others' genitals becomes a "tormenting compulsion." Even more independent an impulse than scopophilia, cruelty comes easily to the child, for the affect of pity, like shame, develops late. ${ }^{14}$

In his conflation of scopophilia, exhibitionism, and cruelty, Freud appears to suggest that these drives, rather than depending on sexual identity or feeling, manifest themselves as forces with their own agency, onerous demands, and power. Moreover, these drives' interrelated qualities hinge on pitilessly attempting to exert dominance over the entire exhibitionistic spectacle. Voyeurism curdles into a desperate sorrow, forever attempting to outwit more powerful repressive forces, while never relinquishing its essentially pitiless agenda to force the gaze-object to submit to the gazing subject. In terms of Coverdale's gaze, the masochism of his own onanistic voyeurism never mitigates the cruelty inherent in his own relentless desire to possess through his ravenous eyes.

Important valences unite Blithedale and Three Essays. Both works relentlessly assign zoological "types" to sexual and gendered categories while perpetually insisting on the fundamental cruelty of desire's self-propagating exertions. Both works also insist that, far from signifying mere isolate self-regard verging on solipsism, onanistic activity only incites desire for the incorporation, through scopophilia, of the desired other; in fact, onanistic voyeurism becomes an ingenious strategy not only for connecting to others but also for possessing and memorializing them, pressing them permanently on what Wordsworth called the mind's unblinking "inward eye" ("I Wandered Lonely as a Cloud") where they can be made to "flash" at will. The chief relevance of Freud's work here lies in its insistence on seeing cruelty and torment as inherent aspects of scopophilia generally, and voyeurism specifically.

In a manner distinct from Freud's, Lacan also fuses gendered anxi- 
eties and theoretical formulations of the gaze. For Lacan, writes Robert Samuels in a Lacanian reading of Hitchcock films, the "ego is pure nothingness. . . [T] [Te subject is narcissistically invested in all of its external representations. ... [T] he subject represses any awareness of its own nothingness or its own lack of representation." Desperately attempting to avoid any confrontation with its own lack, the ego projects it "into the place of the Other," then using "this nothingness, or what Lacan called the 'object' (a), as a cause of its own desire or anxiety. In our current civilization and social structure, this dialectic between the Imaginary state of consciousness and the projected object of nothingness is most often played out in gendered and racial terms." ${ }^{15}$ Like Jeff in Hitchcock's Rear Window, Coverdale perpetually seeks to elude knowledge of his own insubstantiality by forever busying himself with the "external representations" of his own narcissism, i.e., the other Blithedalers, who also conveniently provide him with an external cause for his own marginalization ("How little did these two women care for me" [115]). But rather than projecting his own nothingness exclusively on female characters, who can then conveniently embody the fearsome lack/castration he disavows in himself, Coverdale projects his own nothingness onto male characters as well, most strikingly the mesmerist Westervelt, who embodies Coverdale's "lack" in a vividly homophobic manner.

Inadvertently or otherwise, slippages between homoeroticism and homophobia characterize Lacan's treatment of the gaze, as they do Hawthorne's. The subject of the gaze seeks to see the "object as absence." ${ }^{16}$ As Lacan writes,

What the voyeur is looking for and finds is merely a shadow, a shadow behind the curtain. There he will phantasize any magic of presence, the most graceful of girls, for example, even if on the other side there is only a hairy athlete. What he is looking for is not, as one says, the phallus-but precisely its absence, hence the pre-eminence of certain forms as the objects of his search. ${ }^{17}$

Lacan's formulation excludes potential feminine and/or queer voyeuristic desire. We may wonder, though, what would happen if this voyeuristic subject were queer. If the queer voyeuristic subject seeks a literal phallus rather than a phantasmatic ideal, symbolic one, the phallus of the hairy athlete who is no goofy, farcical booby-prize but the actual focus of the male subject's fantasy (by making him hirsute and athletic, Lacan makes this masculine object especially homoerotic), what might he find on "the other side"? If Lacan is unable here to imagine actual male fantasy for another male, he nevertheless pro- 
vides a means whereby homoerotic voyeuristic fantasy may be considered. If Coverdale, as moved by Hollingsworth's as he is by Zenobia's or Priscilla's beauty (perhaps even more so), projects his own nothingness upon Hollingsworth, and upon Westervelt, does he find merely the shadow he seeks, the absence in which his own nothingness may be projected?

In the provocative relay among subject, gaze, gender, and otherness that organizes The Blithedale Romance, Hawthorne parlays his own gendered and sexual anxieties into the only first-person narrator of his novels, who then projects his own anxieties into the beckoning void of the other characters whom Coverdale voyeuristically fetishizes. In Lacanian terms, Hawthorne may be said to project his own sense of gendered nothingness into Coverdale, who then projects his own onto Hollingsworth and Westervelt, freeing himself of it, even more successfully freeing Hawthorne - now at an even greater, safer remove of it. Yet the uncannily unexpected occurs: the text - the void, the otherized space, the shadow that ostensibly marks an absence--will swerve about to reveal another set of eyes, its own; they look back on the subject desperately attempting to escape its own insubstantiality through its projected gaze.

\section{Medusan Manhood}

If Coverdale describes himself in a manner that suggests the self as Panopticon, or figures his mind as a pornographic theater in which he can play recorded erotic images, the novel's interest in evoking images of the Medusa take on a special relevance. The head of the panoptical self, the head-as-pornographic theater: Medusan references corroborate the head as a site of danger and excitement but also one of pollution and contagion. If thine head offend thee, cut it off.

Hawthorne referred to himself as the "Decapitated Surveyor" in "The Custom House," thus associating himself with both Perseus, slayer of the Gorgon, and with Medusa herself, a mythological character whose story he retold in his $1852 \mathrm{~A}$ Wonder Book, a work of children's literature. ${ }^{18}$ Hawthorne explicitly uses Medusa-a spectacular subject of the gaze, the ultimate example of the terrible effects of looking, a prime example of male gazing with potentially fatal results-as a symbol in Blithedale. Coverdale obliquely associates Zenobia with $\mathrm{Me}^{-}$ dusa and himself with Perseus, who can see the Gorgon only in a mirror (reflected in his shield) lest he be turned to stone: "Zenobia had turned aside. But I caught the reflection of her face in the mirror" (154). When 
Zenobia as raconteur entertains the Blithedalers, she likens The Veiled Lady to Medusa (102). Anticipating Freud's eloquently shocking formulation of the Medusa myth as representative of the terror of the primal scene, these references to Medusa clearly associate Zenobia with a threateningly vivid, voracious female sexuality. ${ }^{19}$ But what are we to make of Westervelt's equally Medusan manhood? Coverdale also associates the mustachioed, bearded, and odious Westervelt with the Green Man, "hirsute and cinctured with a leafy girdle" (85) whom Marjorie Garber, in a different context, has described as a Male $\mathrm{Me}-$ dusa. ${ }^{20}$ Zenobia, the Medusan harlot, Westervelt, the Male Medusa, and Coverdale, the onanistic voyeur - these three conform to the triptych of Victorian social monsters, as Jonathan Ned Katz puts it, the prostitute, the sodomite, and the onanist, all enemies of the properly reproductive and normative family. ${ }^{21}$

Coverdale immediately, instinctively despises Westervelt, who presumptuously hails Coverdale as "friend" (84). Coverdale's appraisal of Westervelt significantly relates to several themes in our discussion of Hawthorne: Westervelt is "young," "well-developed," "as handsome a man as ever I beheld." Coverdale, however, does not like Westervelt's style of beauty, "though a masculine" one (my emphasis). The problem with it? "He had no fineness of nature. ... [In his eyes was] the naked exposure of something that ought not to be left prominent" (85). Coverdale hates him, he thinks, because Westervelt's "foppish" garb outdoes his own "homely" one (86). But this revelation clinches Coverdale's appalled appraisal:

In the excess of his delight, he opened his mouth wide, and disclosed a gold band around the upper part of his teeth; thereby making it apparent that every one of his brilliant grinders and incisors was a sham.... I felt as if the whole man were a moral and physical humbug; his wonderful beauty of face, for aught I knew, might be removeable like a mask; ... [there was] nothing genuine about him.... [I was wrought with] the contagion of his strange mirth. (88-89)

If Hawthorne ambivalently regards Fanshawe and Dimmesdale as beautiful young men blighted by onanism, no ambivalence, only a complete hatred, characterizes his response, through Coverdale, to Westervelt. In a provocative essay, Benjamin Scott Grossberg discusses the chief impasse between Coverdale and Hollingsworth as the incompatibility between Hollingsworth's homoerotic desire and Coverdale's queer desire, which encompasses all of the Blithedale community, male and female alike. Yet Grossberg does not grapple with 
the intensely phobic manner in which Coverdale describes Westervelt - surely a disruption of a marvellously omnivorous queer sensibility. ${ }^{22}$

Westervelt's monstrous mouth, artificially constructed, yawns open like a technologically engineered vagina dentata, with mechanized teeth and draw-bridge flexibility. His mouth, prime feature of his Medusan manhood, equates effeminate males (Westervelt being "foppish") with artificiality, the physical blight of moral depravity and "contagion." If Hawthorne previously treated the effeminate male with a certain degree of sympathy, in Westervelt he throws him to the wolves. (He continues to see Westervelt-types-at the hotel, he spies on a "young man in a dressing-gown, standing before the glass and brushing his hair, for a quarter-of-an-hour together" [140].)

Not only does Hawthorne's depiction of Westervelt homophobically correspond to Jacksonian mythologies and cultural dictates about European dandyish, effeminate artificiality versus sturdy American naturalism, ${ }^{23}$ but it also reveals a great deal about Hawthorne's own anxieties about his manhood, under constant threat from those in his circle. Hawthorne frustrated people who associated him with feminine qualities. Oliver Wendell Holmes is reported to have "complained that trying to talk to Hawthorne was like "lovemaking.' Hawthorne's 'shy, beautiful soul had to be wooed from its bashful pudency like an unschooled maiden.'"24 Emerson and Hawthorne shared a strange, jangly friendship. Hawthorne and Sophia lived in the Old Manse, the home in Concord, Massachusetts that had been built for Emerson's grandfather and in which Emerson wrote his famous essay, Nature; though often in close proximity to each other, both men appeared to regard the other with suspicion. ${ }^{25}$ Emerson, for his part, remarked in an 1838 journal entry that Bronson Alcott and Hawthorne together would make one man. ${ }^{26}$ Hawthorne suffered the slings and arrows of charges of effeminacy even after his marriage to Sophia, who was forced to defend her husband against charges of "womanish weakness" from her own family after their wedding in the summer of $1842 .{ }^{27}$

Hawthorne imbues Westervelt with the calumniated qualities lobbed against the writer himself-foppishness, artificiality, effeminacy. A scapegoat, Westervelt bears these socially undesirable, deviant traits with a smirking gruesomeness that physically manifests his inner depravity. ${ }^{28}$ At the same time, Westervelt's almost ectoplasmically multivalent sexuality encompasses both the dandy as effeminate fop and the diabolical womanizing dandy, who leaves ruined women in his Valmont-like wake. Hawthorne therefore presents 
himself as an ornery subject for a queer theorist to handle. His repulsion at effeminacy and at male-male bonds-while potentially antipatriarchal-carries as well a deeply homophobic charge. ${ }^{29}$ Yet his idealization of male beauty-which amounts to a refracted narcissism, an autoerotic/homoerotic relay among author, fictive mirror-image, and, if present, a spectator (usually, but not always, a woman) who acts as conduit - charges his work with considerable homoerotic power. As Robert K. Martin has written, and Scott Derrick echoed, Coverdale seems as drawn to as he is freaked out by Westervelt's disconcerting erotic spectacle. ${ }^{30}$

Coverdale's loathing of Westervelt can be read as a specific feature of a general erotophobia that seemed to characterize Hawthorne's reactions to Fourierianism. Hawthorne left Brook Farm, the famous, failed utopian communal experiment, before it adopted Fourierian philosophy in 1843; The Blithedale Romance is, of course, Hawthorne's roman-a-clef depiction of his Brook Farm experiences. Despite considerable efforts on the part of Albert Brisbane, an American who tried to reimagine and reshape the Fourierian phalanstery system to make it more palatable to American tastes, Fourierian projects like Brook Farm received stinging criticism that centered around the belief that Fourierian communities abolished marriage and promoted polyamorous relations. ${ }^{31}$ Certainly, Fourier's own theories provided a deeply radical alternative to conventional middle-class morality. Hawthorne and his wife Sophia both read Fourier's writing (in French) and expressed disdain; Hawthorne, reported Sophia, was left "thoroughly disgusted" by what he read. ${ }^{32}$ Having read deeply in Fourier himself before writing the novel, Hawthorne reacted, in Blithedale, to the unadulterated, unAmericanized version of Fourierian utopianism, which promised polyamorous potentialities ranging from "'vestalic' virginity" to "complete promiscuity, both heterosexual and homosexual." Hawthorne cringed at the possibilities suggested by the seemingly imminent realization of Fourier's "New Amorous World." ${ }^{33}$

Another factor may account for the homophobic depiction of Westervelt: meeting Herman Melville set the stage for writing The Blithedale Romance. The Blithedale Romance's extraordinarily pushpull relationship to male-male desire eerily resembles the dynamics of the Hawthorne-Melville relationship. Certainly, Hawthorne's own feelings towards same-sex intimacies deepened over time - into a genuine disgust. In his first experiences visiting the Shaker communities, Hawthorne found them odd but rather quaint. But, visiting them again-significantly, with Melville-in the period in which The Blithedale Romance was written, Hawthorne expressed contempt, and 
genuine revulsion, for same-sex Shaker sleeping arrangements. ${ }^{34}$

While his depiction of Westervelt as a bionic fop reeks of homophobic disgust, as a whole the novel's depiction of manhood radically critiques national enforcements of masculine identity, themselves pinioned on homophobic ideologies. The fears about his effeminacy surrounding Hawthorne especially around the time and the site of his marriage were only one dimension of homo-threat in Hawthorne's life. Others came from national currents in the construction of American manhood. The 1850 s were a significant decade in the conflation of masculine character and physical strength. "In the three quarters of a century after the American Revolution, bourgeois Northerners showed the deepest concern for manhood in its moral, social, and political meanings, while placing a lesser emphasis on the male body," writes $E$. Anthony Rotundo. "Then, in the second half of the nineteenth century, this relative emphasis began to change." Middle-class men began paying "assiduous attention to their bodies." Beginning in the 1850 s, a "vogue of physical culture" became a mania that would be a fully entrenched aspect of American masculinity by the end of the decade. ${ }^{35}$ Blithedale's critique of this newly hypermasculinist model of American manhood involves two seemingly unrelated yet overlapping metaphorical themes: zoological allusions and the male/tourist/ voyeuristic gaze.

\section{In a Pig's Eye}

The dangers of the gaze perpetually confront Coverdale. Interrupting their Comus-like masque in the forest, Coverdale gapes at the Blithedalers garbed as Indians, Jim Crow negroes, Arcadian shepherds, Shakers, the goddess Diana, and other oddly assorted figures, suggestive of the hellish forest orgy of "Young Goodman Brown" in its decadence. When these revelers spot Coverdale, they give chase, making him feel alternately like Actaeon, the young hunter who accidentally spied on the naked goddess Diana bathing in a pool (after she turns him into a stag, his own dogs kill him), and a "mad poet hunted by chimaeras" (195) (inverting the usual order of people chasing chimeras). The forest frolic in which Coverdale observes the Blithedale masque suggests another-Pentheus, in Euripides's The Bacchae, spying on his mother reveling orgiastically amongst her fellow Maenads, female worshippers of Dionysius who become wildly drunk and tear animals apart with their hands. Discovering Pentheus, they decapitate him; his own mother, still in a mad bacchic haze, walks around 
with his head on a stick. Unmentioned yet suggested by Coverdale's adventure, the Pentheus story corresponds to the Medusan theme of castration/decapitation.

The Blithedalers' retaliatory chase after Coverdale exposes him to the returned gaze, a central theme in the novel. No mere passive spectacle, the Blithedalers look back at Coverdale-at us - violently forcing us to account for the spying sacrilege of our gaze, much as Marion Crane's eye in Hitchcock's 1960 Psycho unflinchingly looks back at us for having so long looked at her. I borrow the term "the returned gaze" from Wheeler Winston Dixon, who argues that film "acts upon us, addressing us, viewing us as we view it, until the film itself becomes a gaze, rather than an object to be gazed upon." The returned gaze can produce moments in which the "film structure watches us," when we "feel the look of the image being turned against us, surveilling us, subjecting us to the 'look back' of the screen." Dixon argues that "film itself constitutes a body, a living being ... that ... views its potential audience, holds them in its gaze, subjects them to the same sort of reciprocal surveillance that is experienced between prisoners and guards, a state that leads the viewer, inevitably, to look with her/ himself. ${ }^{36}$ The returned gaze is a highly ambivalent phenomenon, capable of both radical effects and reactionary forms of discipline.

Taking Dixon's argument in a different direction, I argue that the returned gaze can be a moment of radical resistance to the domination of the patriarchal male gaze: the objects--women, sexual deviants, the racial other-squashed beneath it return the subject's gaze, occasionally with a defiance that can be read as counterattack. When Zenobia calls upon Coverdale's voracious gazing of him-his excessive "eye shot"-she is both questioning and undermining the structure of patriarchal power that enables Coverdale to believe he can gaze unabashedly. I am as interested in returned gazes within narrative forms such as novels and films as I am in the capacity for form itself to function as a form of the gaze.

Hawthorne's critique of 1850s hypermasculinity relies on the returned gaze, as does another aspect of the novel's gendered project, Coverdale's zoologies of gender and Hawthorne's parodistic treatment of gendered stereotypes. Throughout the novel, Coverdale, a zoological categorizer of people by sex, relentlessly "pegs" his fellow fictive figures - and by implication, his readers-with broad essentialist generalizations. These generalizations point to conservative impulses in Hawthorne, especially regarding constructions of gender. But they have a radical side, too: through them, Hawthorne critiques, intentionally or otherwise, American hypermasculinity and its concomi- 
tant misogyny. Though Coverdale likens Blithedale to the "Golden Age," the first age in Greek myth and a time before women were created (67), he also bristles at and bucks against male dominion.

"I hate to be ruled by my own sex," reveals Coverdale, for it "excites my jealousy and wounds my pride" (112). Men with an "overruling purpose" like Hollingsworth have "no heart, no sympathy, no reason, no conscience," are "not altogether human" (65). Perhaps this is the fault of the male species itself- "we really have no tenderness" (38). Again, confirming what men "are" through negation, Coverdale observes that men naturally contemn those weak, diseased unfortunates who "falter and faint" in the "rude jostle of our selfish existence" (39). Coverdale suspects that Hollingsworth has come among them only because, having no "real" sympathy, he is as estranged from life as they now are (51). While girls, despite their Pearl-like wildness, play with a "harmonious propriety," boys play "old, traditionary games," "according to recognized law"; this may not sound so very terribly ominous, but Coverdale concludes: "young or old, in play or in earnest, man is prone to be a brute" (68). (I am reminded of the ad campaign for Anthony Minghella's 1999 film version of Patricia Highsmith's novel The Talented Mr. Ripley: "Why is it that when men play they always play at killing each other?") Though highly conventional markers of femininity bestrew the novel-Zenobia's hothouse flower, associating her with Beatrice, Rappacini's ill-fated daughter (41), Priscilla's purse (intriguingly, Coverdale reveals that he, too, possesses one) (33)-especially sharp spikes line the markers of manhood.

Though a seeming radical, Hollingsworth reveals himself to be a traditional male in the worst sense, emerging as a great spokesman for domestic violence. Violently aghast at Zenobia's suffragist philosophy, Hollingsworth deems women who strive for equal rights "poor, miserable, abortive creatures," "petticoated monstrosities"-all but explicitly assigning them a sapphic identity. "I would call upon my sex," rails Hollingsworth, "to use its physical force, that unmistakeable evidence of sovereignty, to scourge them back within their proper bounds!" (114). Hollingsworth decries women for failing to adhere to normative gendered stereotypes as he fully adheres to his own. Crucially, Hawthorne puts a strident testimonial to "physical force" as the chief evidence of natural male "sovereignty" in the mouth of an increasingly contemptible, misogynistic character.

Coverdale's sympathies, by contrast, seem firmly in the women's camp-after Hollingsworth threatens Zenobia, Coverdale shares in what he presumes to be her rage at this "outrageous affirmation of ... 
the intensity of masculine egotism" (114). Self-pityingly wounded Coverdale transmutes his empathy, though, into rancor at the women for failing to care for him, while brutal Hollingsworth, "by some necromancy of his horrible injustice, seemed to have brought them both to his feet!" (115), leaving Coverdale "to shiver in outer seclusion" (116). Coverdale's nearly misandrist contempt for masculinity gives certain passages an especially redolent Hawthornian irony: "After a reasonable training, the yeoman-life throve well with us. Our faces took the sunburn kindly; our chests gained in compass, and our shoulders in breadth and squareness; our great brown fists looked as if they had never been capable of kid gloves" (60). Given the growing antebellum cult of hypermasculinity, and the critical drubbing that Hawthorne's own performance of masculinity received, this description throbs with satirical and political significance.

Coverdale conjectures that Hollingsworth views mankind as "but another yoke of oxen, as stubborn, sluggish, and stupid" (92), and yet his own theories of manhood correspond symmetrically to Hollingsworth's. The apotheosis of the novel's demythologization of male power-achieved precisely by associating it with "brute" strength-is Converdale's encounter with Blithedale's pigs.

Sadly yet bitterly leaving Blithedale after his refusal of Hollingsworth's hand in friendship, Coverdale passes Hollingsworth, as if both were "mutually invisible." What follows is perhaps the most coarsely, palpably visual image in the novel, when Coverdale visits the pig-sty before his departure:

There they lay, buried as deeply among the straw as they could burrow, four huge black grunters, the very symbols of slothful ease and sensual comfort. They were asleep, drawing short and heavy breaths, which heaved their big sides up and down. Unclosing their eyes, however, at my approach, they looked dimly forth at the outer world.... They were involved, and almost stifled, and buried alive, in their own corporeal substance. The very unreadiness and oppression, wherewith these greasy citizens gained breath enough to keep their life-machinery in sluggish movement, appeared to make them only the more sensible of the ponderous and fat satisfaction of their existence. Peeping at me, an instant, out of their small, red, hardly perceptible eyes, they dropt asleep again; yet not so far asleep that their unctuous bliss was still present to them, betwixt dream and reality. (133-34)

The authentically masculine farmer Silas Foster impresses upon Coverdale that he must return to dine on spareribs- "I shall have these 
fat fellows hanging up by the heels, heads downward, pretty soon, I tell you!" Appalled, Coverdale responds that only these "four porkers" are happy in Blithedale, and that it would be better "for the general comfort to let them eat us; and bitter and sour morsels should we be!" (134).

Although the pigs peep at Coverdale for an instant, in slothful sleep rather than assaultive gazing, this passage with the pigs foregrounds by thematizing the issues of gender, voyeurism, zoological typing, and the returned gaze central to The Blithedale Romance. The pig-passage reveals that, despite his efforts at sadistic voyeuristic mastery, Coverdale's own subject position is resolutely one of enforced, abiding masochism. ${ }^{37}$

\section{Flying the Boar}

Confirming their allegorical significance as males, these almost oneiric beasts are called "fellows." "Fellows" echoes Coverdale's earlier analogy between the pigs-acquired shortly after Coverdale arrives in Blithedale-and "the swinish multitude," the "greedy, struggling, self-seeking world" that Blithedale ostensibly rejects and defies (20): the masculine world of commerce and industry.

In his 1853 Tanglewood Tales, a collection of classical myths retold for children, Hawthorne recounts the tale from Homer's Odyssey of Circe and the pigs. ${ }^{38}$ The powerful sorceress Circe turns Ulysses's men into pigs, just as she has transformed other hapless male victims into the various animals that pace around her haunted palace. Homer often depicts Ulysses's hungry men, who make the fatal error of eating the sun god Helios's cattle (Book XII), as numbskulls. But Hawthorne extravagantly emphasizes the men's innate beastliness to a degree that bears closer investigation.

As Ulysses's men marvel at their luck at being in the beautiful Circe's beautiful palace and their impending feast, they whisper and "wink" at each other, little realizing Circe's contemptuous plans for them. "It would really have made you ashamed to see how they swilled down the liquor and gobbled up the food," the narrator sighs. "They sat on golden thrones, to be sure; but they behaved like pigs in a sty." The squeamish narrator remarks, too, that it "brings a blush into my face to reckon up, in my own mind, what mountains of meat and pudding, and what gallons of wine, these two and twenty guzzlers and gormandizers ate and drank" (1396).

Disgusted by the men's behavior-which she has herself enabled 
or orchestrated-Circe calls them "wretches," saying it will take little magic to transform them into the pigs they have already emulated.

They would have wrung their hands in despair, but, attempting to do so, grew all the more desperate for seeing themselves squatted on their hams, and pawing the air with their fore trotters. Dear me! what pendulous ears they had! what little red eyes, half buried in fat! and what long snouts, instead of Grecian noses! (1397)

Hawthorne's description of the men as pigs, "buried in fat," seeing "red" as the Blithedale pigs do, corroborates and extends the metaphorical implications of the peeping pigs in Blithedale. ${ }^{39}$ But in the 1852 novel, the pigs gaze at Coverdale in an oddly, uncomfortably serene and uncanny knowingness; though being prepared for slaughter, these pigs look out from a zone of almost godlike imperturbability. By the writing of "Circe's Palace," the metaphorical pigs have lost their previous authority, power, indifference. Their association with men and manhood takes on a cursed quality, an air of desperation and despair as these pigs now see themselves for what they are. What is metaphorical in one text becomes literal in the next: pigs that resemble men become pigs as men.

Circe's own avidity for transforming the men into the pigs she always already views them as-confirmed by the knowing looks exchanged amongst Circe and her crew as they supply the men with the means of their porcine obscenities-carries over Zenobia's appalled disappointment at Hollingsworth's animalistically brutish behavior, but adds what vulnerable Zenobia did not: a retaliatory campaign against mankind. Tanglewood's Circe acts as Zenobia's avenging sorceress-angel. If "Circe's Palace" functions as sequel to Blithedale, as I argue it does, it is significant that Hawthorne must reach into the recesses of classical literature to "solve" the modern erotic problems of this antebellum utopian community. Rather than using mythic reference to underscore contemporary issues, Hawthorne infuses a retold myth with topical gendered anxieties.

Lee Edelman, writing about W. E. B. Du Bois and African-American manhood, argues that "manhood" . . . is itself a performance for the gaze of the Other ... always the paradoxical display of a masculinity that defines itself through its capacity to put others on display while resisting the bodily captation involved in being put on display itself." 40 Flawed and flagrantly theatrical, Coverdale's performance flails about in its desperate attempts to convince us, himself, the Blithedalers that he is indeed master of his gaze. Coverdale's fantasy of masculine con- 
trol never convinces, being always transparent as such. Directly challenging any attempt to prove that he controls the directionality of his pseudo-masterful gaze, the pigs return his gaze, stopping his eyes dead in their tracks with their porcine own. They put him on display.

Discussing the returned gaze of Andy Warhol films, Dixon notes, "When watching Vinyl one gets the continual and uneasy feeling that one is being watched, being judged, by Warhol's returned gaze, a gaze that is almost solely a product of the performance space of the film, rather than the 'look' of the actors.... [ Vinyl leaves] the viewer viewed, the gaze returned." Just as Warhol's films seem to look back at the viewer with a life of their own, with a strange air of judgment, the pigs return Coverdale's gaze and our own, resisting any facile notion of pity (recall Coverdale's seeming concern for them; their returned gaze suggests that Coverdale will always already be the devoured meal he fears they will become; as he half-mockingly offers himself and his fellow Blithedalers in their place, they seem to say with their eyes, "I'd worry about myself if I were you."). The pity they reject by dreamily returning his gaze is the only means whereby Coverdale might have been able to dominate his vision of them, have enjoyed even a fleeting sense of mastery.

Moreover, the pigs-animals closely tied to cultural fantasies of fascist masculinity ("pig" for police officers; pigs are the animals who betray their beastly brethren in Orwell's Animal Farm, finally indistinguishable from the "men" to whom they sell out their ideals), and clearly representative of manhood in Hawthorne's work-in debunking any notion of Coverdale's mastery of the gaze, also debunk any notion of a masculine power out there, somewhere, that Coverdale can tap into, exploit. If these pigs-these "fellows"-metaphorically represent male power, they represent, too, a male power wholly exclusive, truly and terrifyingly other. When they stare back, they are not so much a Greek chorus of eyes, sorrowfully reflecting back Coverdale's own inadequacy and desperation, as they are the godlike power of "gender" itself, a sort of oozing pool of "original," essentialist masculinity. With their eyes, they mock Coverdale, just as his own eyes mock themselves. ${ }^{42}$ Within their perverse psychic and corporeal plenitude, the pigs need only peep at Coverdale, a mockery through diminution of his large-scale attempt to overmaster by sustained looking. Freighted with their own gendered typing, Hawthorne's pigs represent a primordial, chthonic form of manhood and masculinity. When Coverdale stares at them and they look back at him, the authority they wield would appear to depend upon their tie to some form of essential, gendered knowledge, an essential masculinity both base and 
debased. To borrow and transform a terrm from Barbara Creed, the pigs embody the monstrous-masculine. ${ }^{43}$

Among other literary monster-men, Shakespeare's Richard III held a strong fascination for Hawthorne, and provides another antecedent for Hawthorne's symbolic imagery of men-as-pigs. In Richard III, the misshapen, murderous king is likened to a hedgehog and a boar. (In the 1996 film version, directed by Richard Loncraine and set in a fascist state, Ian McKellen's Richard, in terrifying boar-face, snarlingly stares at us.) Hastings, who will soon be beheaded at Richard's behest, scoffs at Lord Stanley's dream of a boar-that is, Richard-pursuing him:

To fly the boar before the boar pursues

Were to incense the boar to follow us,

And make pursuit where he did mean no chase. (III.2. 28-30)

Hastings fails to heed the warning of Stanley's dream, ending up beheaded. Coverdale similarly flees the boar, albeit one always on the chase, eternally incensed to follow him, and us. ${ }^{44}$

If the peeping pigs-passage in The Blithedale Romance rewrites the Odyssey episode in which Circe turns Odysseus's men into pigs, its erasure of women is striking-especially for a writer usually attuned to the interests and suffering of his female characters. Hawthorne rarely paints a nakedly homoerotic tableau; rather, he suffuses an erotic awareness of the intense beauty of both men and women in his work, a sensibility that anticipates Freudian bisexuality. Yet, as Coverdale stares at these hypermasculine pigs, Hawthorne erases Circe and her role as avenging enemy of male power. It is as if Odysseus were forced to confront the symbolic porcine animality of his men without the exculpatory hex of an erotomaniacal sorceress. What Hawthorne constructs here surprisingly resembles Marlowe's queer retelling of the Diana-Actaeon myth in Edward II, which homoeroticizes the story and removes Diana, transformed instead into "a louelie boye in Dians shape." ${ }^{45}$ Hawthorne also retells this myth in The Blithedale Romance.

In Hawthorne, myth becomes a means of metaphorizing manhood and male anxieties. Coverdale confronts his own anxieties about being a man in this polyamorous setting, which includes his homoerotic attraction to and disgust towards Hollingsworth and Westervelt, not to mention the young man he sees from his city window. Beautiful, desirable young men haunt his fiction alongside lushly beautiful women like Georgiana (with her high-fashion flaw/mole) and Beatrice Rappacini. Removing the equally pressing beauty of women from this 
passage, Hawthorne stages a confrontation between a man and maleness - with all of its attendant complexities-itself. If homoerotic desire and homophobic disgust equally influence Coverdale's relations with men, which culminate in or are synthesized by the pigs, the novel suggests that homosexuality causes a breakdown of all conventional standards that maintain identity, down to the level of species. ${ }^{46}$ Coverdale likens Hollingsworth to a "polar bear" (25). Mingling his desire and disgust, Coverdale confesses, "I loved Hollingsworth. But. . . . He was not altogether human" (64).

\section{Hawthorne's Hitchcockian Gaze}

The oeuvres of Alfred Hitchcock and Nathaniel Hawthorne share two interrelated themes - the plight of the independent, headstrong, sexually aware woman in patriarchy and the often murderous rivalry between men within patriarchal capitalism. Both Hawthorne and Hitchcock - in a manner concomitant with their misogyny-express a romantic, anguished interest and identification with the wronged woman. Hester Prynne, Zenobia, and The Marble Faun's Miriam resemble Hitchcock's embattled, troubled, and determined heroines like Alicia Huberman of Notorious, Psycho's Marion Crane, and Marnie's titular protagonist. Much like Coverdale, Cary Grant's Devlin in Notorious (1946) treats the "bad woman" Alicia Huberman (Ingrid Bergman) with contempt, yet maintains a hidden sympathy for herhe is in love with her, a secret he assiduously hides, until the climax. And his sympathy towards her manifests itself in his contempt for the bureaucratic men who put her to work as a government spy infiltrating a Nazi stronghold in Brazil. In a meeting with his fellow government men, Devlin defends Alicia's honor to one odious man who calls her a "woman like that." Yet towards Alicia Devlin he remains aloof, until it is almost too late. At odds with the homosocial, treating women with an ambivalence that borders on sadism, Devlin resembles many Hawthorne men, especially Coverdale.

Rear Window also circulates and examines many of the same tensions and themes in The Blithedale Romance. Jeff, an incapacitated photographer with a broken leg, temporarily wheelchair-bound and peeping on his neighbors, suffers and wounds in Coverdale fashion. Jeff wrangles with his war buddy detective Tom (Wendell Corey), who refuses to believe that Jeff has uncovered the murder of Mrs. Thorwald by her husband Lars (Raymond Burr) and mercilessly satirizes Jeff's sleuthing. Jeff enjoys and eludes the erotic entrapments of 
the film's "21" Club-hopping fashion-plate glamour-girl with a brain, Lisa Fremont (Grace Kelly). Jeff's apartment is his inviolate bower, the murders and other perversities of his neighbors his questionably distilled vintage.

There is a famous sequence in Rear Window that corresponds to the peeping-pig episode in The Blithedale Romance, of particular relevance to the issue of masculinity and the returned gaze. Desperate to impress the reticent, cynical, sexually reluctant Jeff, who claims they have no future together, Lisa boldly-a bit maniacally-ventures into Lars Thorwald's apartment to find incriminating evidence, Mrs. Thorwald's wedding ring especially, the logic being that she would never, as her husband claims, have gone off on a trip without it. As Jeff and hard-bitten nurse and masseuse Stella (Thelma Ritter) watch, Lisa makes her way through Thorwald's apartment, Jeff on the verge of calling the police and getting Lisa out of there. Suddenly distracted by the imminent suicide by pill of the sad woman in a first-floor apartment whom Jeff has dubbed Miss Lonelyhearts, Jeff fails to make his phone call to the police. "The music's stopped her!" cries Stella, discovering that the musical efforts of the equally lonely composer above have stalled Miss Lonelyheart's suicide attempt. As Jeff and Stella stare at the transfixed Miss Lonelyhearts, Thorwald returns to his apartment. Shortly afterwards, he discovers Lisa, who attempts to convince him that there's a perfectly good reason why she's in his apartment. Thorwald grabs her, they struggle, and then--in one of the most terrifying and precisely engineered suspense moments in Hitchcock's considerable arsenal-the lights are knocked out, and darkness fills the screen, as Jeff, his face contorted in helplessness and guilty despair, says, "Oh, Stella, what am I going to do?" In a moment no Foucauldian could love, the police arrive and restore order. (With Hitchcock's established phobia about the police, one wonders how he could, either.) The lights come back on. Triumphantly, the now rescued Lisa, her back to all of us, taps her finger, upon which glints in merry light Mrs. Thorwald's wedding ring.

As the finger taps and the ring flashes, Thorwald realizes that he is being watched. He stares back at Jeff staring at him, returning Jeff's gaze. It is little wonder that guilty Jeff frantically attempts to elude Thorwald's gaze, which penetrates him with shared knowledge, complicity, understanding, recognition, and that curious air of judgment. "You're no different from me," Thorwald seems to be saying to Jeff. "I may have killed my wife, but since you sent your girlfriend to my apartment, where I could have easily killed her and nearly did, you have no right to judge me." In these distinct yet thematically linked 
episodes, Hawthorne and Hitchcock both use the gaze as a means of recording male anxiety about masculinity itself, as a means of looking at masculinity through male eyes, truly a sight hateful, sight tormenting.

It is precisely within the returned gaze of The Blithedale Romance that Hawthorne's conservatism and radicalism coalesce. Precisely because Hawthorne's greatest political accomplishment is his consistent and consistently unflinching critique of conventional, compulsory forms of manhood and masculinity, which has implications not only for heteromanhood but for queer manhood as well, I find the strain of masculinism in treatments of Hawthorne's politics unsettling. Since the 1980s, in a critical movement spearheaded by Jonathan Arac and Sacvan Bercovitch, a broad critique of Hawthorne's ambiguity - seen as, among other things, an aesthetic maneuver for expressing by camouflaging ambivalence over the slavery issue or for providing a seeming array of possibilities to us as desiring subjects while actually depriving us of all choice, making us complicitous with our own deadening socialization-has denatured Hawthorne's aesthetics by seeing it in strictly political terms ${ }^{47}$ The issues in this critique are painfully, pressingly important, but the critique in its Arac-Bercovitch cast suffers from an inability to see aesthetics in anything other than ideological terms.

Jonathan Arac's elegant "The Politics of The Scarlet Letter" remains an index of the poststructuralist critique of Hawthorne's work, centering on the slavery question that Hawthorne kept, by all accounts, ducking. The issue of slavery and Hawthorne's reponse to it is of vital importance, particularly considering Hawthorne's years-long, passionate friendship with his former Bowdoin classmate Franklin Pierce, and his political appointments within the Democratic party. Yet what remains curious in Arac's approach-emblematic of the broadly Foucauldian approach to nineteenth-century American writing he and Bercovitch innovated-is his reliance on masculinist gendered standards.

Arac rather nostalgically reclaims Hawthorne, along with Stowe, as a self-consciously political author writing in a time when it "was not yet taken for granted that literature must be intransitive, useless as well as harmless." Hawthorne, Arac notes, "recognized slavery as potentially divisive, and he did not favor slavery; he only urged that nothing be done about it." Hawthorne "envisaged" the "logic of romance" for American politics, since he shuddered at the thought of the "horrible convulsion," "this dreadful convulsive action" as Sophia Hawthorne echoed, of the Civil War. "Action is intolerable; character 
takes its place" for Hawthorne, Arac surmises. Hawthorne inherits the Romantic reinterpretation of Hamlet, its rejection of Aristotelian theories of character as one who acts. In Hawthorne's narration-heavy writing, literary character becomes instead "one who is known." Hawthorne's own political character, in Arac's reading, emerged on the same lines: "Hawthorne's name circulated as a sign in a complex system of exchange that made it worth the [Democratic] party's while to provide him a livelihood, and that gave him the character of a Democrat without requiring action." Reminding us of Hawthorne's "abject identity with Coverdale," Arac reduces Hawthorne's life and work to a philosophy of "Let others do it." 48

Clearly, Hawthorne describes ambiguous male sexuality in phobic fashion: his Westervelt is a triumph of sodomitical/effeminate typing. Yet his analysis of normative forms of masculinity-all of those asides about the essentially brutish natures and increasingly regularized bodies of men, not to mention the possibility that what Coverdale seeks is in fact Lacan's hairy athlete, along with Coverdale's uncanny confrontation with a terrifyingly otherized form of manhood in the peeping pigs, peeping back at him, tinged with the author's own anxieties about his gendered identity and how it was perceived-does provide an important critique of the construction of gender in Hawthorne's America.

\section{Notes}

'See Mulvey, "Visual Pleasure and Narrative Cinema," Screen 16, no. 3 (1975), 618, repr. in Visual and Other Pleasures (Bloomington: Indiana Univ. Press, 1989), 14-27; "Afterthoughts on 'Visual Pleasure and Narrative Cinema' Inspired by King Vidor's Duel in the Sun," Framework 15/16/17 (1981), repr. in Visual and Other Pleasures (29-38). I do not mean to denigrate Mulvey's bold and revolutionary work; as much as anything, I am critiquing its continued hold on critical accounts of the gaze. Susan White charts the "almost hypnotically powerful effect on feminist film theorists" of Mulvey's work, and the ways in which recent critics, after many years of laboring over Mulvey's paradigms, have argued that female desire, so elusive in "Visual Pleasure," can erupt in the "gaps" and fissures" of dominant texts, and that, moreover, the image of universalized white, middleor upper-class woman Mulvey deploys itself needs to be painstakingly problematized. See White, "Problems of Knowledge in Feminist Film Theory," Alfred Hitchcock: Centenary Essays, ed. Richard Allen and S. Ichii-Gonzales (London: BFI, 1999), 278-98.

2 "Although the gaze might be said to be 'the presence of others as such,' it is by no means coterminous with any individual viewer, or group of viewers. It issues 
'from all sides,' whereas the eye '[sees] only from one point.'" Kaja Silverman differentiates the eye or the "look" from the gaze, making the analogy that the eye and the gaze are, in psychoanalytic theory, as distinct as penis and phallus. Drawing from Lacan, Silverman elaborates that, far from lending an air of mastery to the subject, voyeurism renders the looking subject "subordinated to the gaze," disturbed and overwhelmed, and overcome by shame. In Lacanian gaze theory, "the possibility of separating vision from the image" is called "radically into question," and along with it the presumed "position of detached mastery" of the voyeuristic subject. This clarification of Lacanian gaze-theory has bold implications for feminist film theory, whose proper interrogation of the male look has not "always been pushed far enough. We have at times assumed that dominant cinema's scopic regime could be overturned by 'giving' women the gaze, rather than by exposing the impossibility of anyone ever owning that visual agency, or of him or herself escaping specularity." See Silverman, Male Subjectivity at the Margins (New York: Routledge, 1992), 130, 146, 152. This view of the voyeuristic subject not as victim but as vulnerable and fragile insofar as he can never achieve the sense of mastery that fantasmatically impels his very voyeuristic project informs my reading of The Blithedale Romance.

${ }^{3}$ Suzanne R. Stewart, Sublime Surrender: Male Masochism at the Fin-de-Siècle (Ithaca: Cornell Univ. Press, 1998), 10.

${ }^{4}$ Ellen Langton's desiring appraisal of Fanshawe's troubled beauty, Hester's ardent desire for Dimmesdale, seemingly meek, wan, sweet Alice Pyncheon's frank physical appraisal of Matthew Maule are among the many examples of the female desiring gaze in Hawthorne's work. As I argue in Men Beyond Desire: Manhood, Sex, and Violation in American Literature (New York: Palgrave Macmillan, 2005), the men of prominent nineteenth-century texts (such as Fansahwe, Natty Bumpo, Dimmesdale, Stowe's Tom) are often rendered as inviolate, opposed to both female and homosocial/homoerotic desire. Their inviolability makes them fields of erotic play through which female desirers, and queer desirers, acquire opportunities to gaze, a surprising agency to roam the inhospitable expanse of beautiful and undesiring men. In this essay, I am considering the implications for queer theory of a complicated male subjectivity, such as we find in Hawthorne, that oscillates between spectator and object positions, but the fuller understanding of these questions can only come through further work on the implications for feminist literary theory about Hawthorne's representation of manhood and the gaze. I focus on the queer implications of Hawthorne's work, especially in terms of the gaze, but this focus hardly exhausts the potentialities of Hawthorne gaze-theory. The feminist implications of the desiring gaze in Hawthorne's work are just as rich, complex, and tantalizing, and these, too, deserve further study.

${ }^{5}$ The bachelor has been established as a powerfully interesting figure in recent critical work; for an unpacking of the relationship between the bachelor and the "third man" in male-male-female triangles, see Katherine V. Snyder, Bachelors, Manhood, and the Novel, 1850-1925 (Cambridge: Cambridge Univ. Press, 1999). In this light, it is remarkable that Pearl describes Dimmesdale, interrupting her forest fun with her mother Hester, as "the third man" (10). In The Blithedale Romance, Coverdale provides the crucial fourth side to the triangle, "being writer and reader as well as participant in the dramatic action he describes." See Allan 
Gardner Lloyd Smith, Eve Tempted: Writing and Sexuality in Hawthorne's Fiction (Totowa, NJ: Barnes and Noble, 1984), 73-74.

${ }^{6}$ Nathaniel Hawthorne, The Blithedale Romance (1852; New York: Norton, 1978); hereafter cited parenthetically. In classically Hellenizing fashion, the walls of the Hawthornes' West Newton home, which Nathaniel christened "The Wayside," "were adorned by a bust of Apollo" and "Mrs. Hawthorne's drawing of Endymion." No more perfect emblems of Hawthorne's own enigmatic beauty and personality could have existed, and it is little surprise that they adorned their home, or that Sophia drew the figure so often present-in my view-in her husband's fiction. See Randall Stewart, Nathaniel Hawthorne: A Biography(New Haven: Yale Univ. Press, 1948), 124.

${ }^{7}$ Interestingly, the allegorical Hawthorne-figure in Herman Melville's poem Clarel is called "Vine." For a wonderful queer reading of Clarel in terms of Melville's love for Hawthorne, see Robert K. Martin, Hero, Captain, Stranger: Male Friendship, Social Critique, and Literary From in the Sea Novels of Herman Melville (Chapel Hill: North Carolina Univ. Press, 1986), 96-99.

${ }^{8}$ In calling Coverdale the self-as-panopticon, I evoke Jeremy Bentham's original design for supervision of prison inmates and the now conventional Foucauldian ominousness of social surveillance, but I do not mean to offer a Foucauldian argument in this essay. Coverdale's panoptical selfhood explodes the idea of a functioning means of surveillance that can in any way control or shape or manipulate what it sees. I see this essay as a kind of sequel to E. Shaskan Bumas's "Fictions of the Panopticon: Utopia and the Out-Penitent in the Works of Nathaniel Hawthorne," American Literature 73 (2001), 121-45, a piece full of important insights into early prison reform. But I differ with Bumas's contention that "in Blithedale," Hawthorne "shows the virtually historiographic power of a narrator over narrated events and people, and he judges this power as barren but not much different from other forms of power. In Coverdale, the spy, the voyeur, and the observer overlap" (133). Hawthorne at all times bleakly empties out Coverdale's narrative subject position of power and mastery.

${ }^{9}$ See T. Walter Herbert, Dearest Beloved: The Hawthornes and the Making of the Middle Class Family (Berkeley: California Univ. Press, 1993), 144.

${ }^{10}$ As Hortense Spillers writes in her essay on Uncle Tom's Cabin, "negation becomes an alternate route to confirmation." Hortense J. Spillers, "Changing the Letter: The Yokes, The Jokes of Discourse, Or, Mrs. Stowe, Mr. Reed," Slavery and the Literary Imagination: Selected Papers from the English Institute, 1987, ed. Deborah E. McDowell and Arnold Rampersad (Baltimore: Johns Hopkins Univ. Press, 1989), 44.

${ }^{11}$ For a sustained discussion of inviolate manhood and the antebellum threat of onanism as represented in Hawthorne's first novel, the 1828 Fanshawe, see Greven, Men Beyond Desire, chapter 2.

${ }^{12}$ See Christopher Newfield and Melissa Solomon, "Few of Our Seeds Ever Came Up at All: A Dialogue on Hawthorne, Delany, and the Work of Affect in Vision- 
ary Utopias," No More Separate Spheres!: A Next Wave American Studies Reader, ed. Cathy N. Davidson and Jessamyn Hatcher (Durham: Duke Univ. Press, 2002), 377-408.

${ }^{13}$ Drawing on the work of sociologist John Urry and her own experiences as a stripper, Katherine Frank discusses the "collective gaze"-in which multiple tourists lend glamour to their surroundings-and the "romantic gaze"-which emphasizes solitude and privacy. Coverdale obviously embodies the latter, but one could argue that Blithedale as a whole constitutes a collective gaze. See Frank, G-Strings and Sympathy: Strip-Club Regulars and Male Desire (Durham: Duke Univ. Press, 2002), 28-29.

${ }^{14}$ Freud wrote Three Essays on the Theory of Sexuality in 1905 but kept adding to it until 1924. See Sigmund Freud, Three Essays on the Theory of Sexuality, ed. and trans. James Strachey (New York: Basic Books, 1962), 58-59.

${ }^{15}$ Robert Samuels, Hitchcock's Bi-Textuality: Lacan, Feminisms, and Queer Theory (Albany: State Univ. of New York Press, 1998), 10.

${ }^{16}$ Samuels reads this desire to see not the presence of the object but its absence as a desire on the part of the (male) subject to dominate the object by pushing it to "the limits of the visible and the sayable," an especially relevant goal for the misogynistic subject. Samuels, Hitchcock, 113.

${ }^{17}$ Jacques Lacan, The Four Fundamental Concepts of Psychoanalysis, trans. Alan Sheridan (New York: W. W. Norton, 1981), 182.

${ }^{18}$ Joel Pfister, in The Production of Personal Life: Class, Gender, and the Psychological in Hawthorne's Fiction (Stanford: Stanford Univ. Press, 1991), 101, also notes Hawthorne's identification with the Medusa story.

${ }^{19}$ For Freud, the head of the Medusa suggests part of the terror of accidentally viewing the primal scene that he located in the iconography of the Medusa, which he saw as a representation of the male child's attendant revulsion - the writhing snakes being representations of pubic hair and also compensatory substitutions for the castrated penis (264-65). See Sigmund Freud, Writings on Art and Literature, ed. and trans. James Strachey (Stanford: Meridian, 1997).

${ }^{20}$ In Shakespeare's Ghost Writers: Literature as Uncanny Causality (New York: Methuen, 1987), Marjorie Garber links the gender indeterminacy of Macbeth, the Male Medusa, to "the foliate head or leaf mask which gained enormous popularity in England and throughout western Europe during the Romanesque and medieval periods ... with leaves sprouting from [its face] . . often sinister and frightening. ... [This] Green Man ... embodies a warning against the dark side of man's nature, the devil within" (101-103). This sinister figure represents the union between brutal masculinist power and generative female nature.

${ }^{21}$ Jonathan Ned Katz, The Invention of Heterosexuality (New York: Dutton, 1995), 45. 
${ }^{22}$ Benjamin Scott Grossberg, “The Tender Passion Was Very Rife among Us': Coverdale's Queer Utopia and The Blithedale Romance," Studies in American Fiction 28, no. 1 (2000), 3-25. While I admire Grossberg's essay, his approach to Coverdale's queer sexuality verges on celebratory and eschews its problematic, chilling complexities.

${ }^{23}$ Jacksonian America was growing increasingly aware of, and hostile to, the image of the European dandy, as historian David G. Pugh points out: Jackson "brought earthy wisdom to Washington rather than esoteric knowledge. . . . Their independence from Europe secure, Americans turned upon themselves and found on their own eastern doorstep the cultivated, effeminate enemy of the true democrat." Sons of Liberty: The Masculine Mind in Nineteenth-Century America (Westport, CT: Greenwood Press, 1983), 18.

${ }^{24}$ Quoted in James R. Mellow, Nathaniel Hawthorne in His Times (Baltimore: John Hopkins Univ. Press, 1998), 28.

${ }^{25}$ Mellow, Hawthorne, 195. On the sexual and national politics of Hawthorne and Emerson's relationship, and on Sophia Peabody Hawthorne's role in the Hawthorne marriage, see Renée Bergland, "The Puritan Eyeball, or Sexing the Transcendent," in The Puritan Origins of American Sex: Religion, Sexuality, and National Identity in American Literature, ed. Tracy Fessenden, Nicholas F. Radel, and Magdalena J. Zobrorowska (New York: Routledge, 2001), 93-108.

${ }^{26}$ In his June 13, 1838 journal entry, Emerson wrote of Hawthorne: "Alcott and he together would make a man." See The Heart of Emerson's Journals (Mineoloa, NY: Dover Books, 1995), 32. Sophia's sister Elizabeth Peabody strove to incite enthusiasm for Hawthorne's work in Emerson, who, after reading Hawthorne's "Footprints on the Seashore," an account of a Salem sea-shore day-trip, found that it had "no inside to it." See Carlos Baker, Emerson Among the Eccentrics: $A$ Group Portrait (New York: Viking, 1996), 210.

${ }^{27}$ See Herbert, Dearest Beloved, 140, for a discussion of the Peabodys' opinion of Hawthorne's "suspiciously feminine" manhood. Sophia chided her family for failing to recognize that her husband possessed a "divine poetic manhood, into which feminine qualities are incorporated," as Herbert puts it. They needed, felt Sophia, to better comprehend Hawthorne's androgynous Apollonian qualities as such.

${ }^{28}$ In the early republic, Dana Nelson observes, "European immigrants . . . were increasingly regarded with suspicion, as sources of contamination of the 'democratic' spirit." National Manhood: Capitalist Citizenship and the Imagined Fraternity of White Men (Durham: Duke Univ. Press, 1998), 37. This anti-European and newly nativist sensibility seeped into manhood as a social category, increasingly reimagined as a decisive break with European decadence.

${ }^{29}$ See Mellow, Hawthorne, 610, n. 66, for a very interesting discussion of Hawthorne's "animus" toward his invalid uncle Robert Manning, with whom he was forced to share a bed as an adolescent. Mellow makes the interesting point that this animus appears to translate itself into the association with horticulture on the part of Hawthorne villains such as Rappacini, Chillingworth, and Judge 
Pyncheon: Uncle Robert Manning was also a horticulturist. Whatever their relationship, a wounded quality seems to permeate Hawthorne's depiction of young men, who often flinch against the threat of an older and more powerful male ("Young Goodman Brown," "The Gentle Boy," "The Artist of the Beautiful," "Rappacini's Daughter," The Scarlet Letter); as Mellow notes, this theme may be attributable to a childhood sexual trauma that Hawthorne, who once remarked that "an uncle is a very dangerous thing," may have experienced at the hands of his uncle.

${ }^{30}$ See Robert K. Martin, "Hester Prynne, C'est Moi: Nathaniel Hawthorne and the Anxieties of Gender," in Engendering Men: the Question of Male Feminist Criticism, ed. Joseph A. Boone and Michael Cadden, (New York: Routledge, 1990), 135-36. Martin asserts that at the heart of Hawthorne's male characters' gendered anxieties lies an "unacknowledged, or at least denied, desire for intimate companionship" (138). Scott Derrick concurs: what motivates Hawthorne's rejection of masculine worlds in "The Custom House" essay may stem less from a distance towards them than an unsettling erotic attraction. See Monumental Anxieties: Homoerotic Desire and Feminine Influence in Nineteenth Century U. S. Literature (New Brunswick: Rutgers Univ. Press, 1997), 43-44. While I see a problematic, unsettling homoerotic desire as a factor in the anxiety of Coverdale and other Hawthorne males, revulsion against male intimacy needs to be considered not only as a panicked cover for an actual desire for other men but also as a chafing against compulsory American homosociality. See Greven, Men Beyond Desire.

31 "Fourier's plan for a social system was embedded in a broad philosophical program. Rejecting contemporary individualistic and competitive society, which he called Civilization, Fourier projected a future ideal state of Harmony based on cooperation. He imagined a system of communities, what he termed phalanxes or phalansteries, in which all adults would engage in productive work determined by their interests and be rewarded by a complex scheme of remuneration for both labor and capital." The American Albert Brisbane, who studied in Europe and worked with Fourier before his death in 1837, transmogrified the French philosopher's ideas into an American version that de-emphasized Fourierian irreligiousness and sexual openness, heightening instead Fourierian elements that appealed to "economic and social value." See Helen Lefkowitz Horowitz, Rereading Sex: Battles Over Sexual Knowledge and Suppression in Nineteenth-Century America (New York: Knopf, 2002), 261.

${ }^{32}$ Sophia read Fourier in French, then passed the volume on to her husband. In a passionate discussion with her mother about Fourier, Sophia reported finding his views "abominable"; she noted that while she read a small part, "My husband read the whole volume and was thoroughly disgusted." Sophia acknowledged that his having written after the French Revolution "accounts somewhat for the monstrous system" he proposed; Mother Peabody responded by saying that the French "have been and are still corrupt." See Mellow, Hawthorne, 248-49.

${ }^{33}$ See Horowitz, Rereading Sex, 262-63.

${ }^{34}$ See Mellow, Hawthorne, 378-79. Touring a Shaker village with Melville, Hawthorne, observing quarters in which men slept in the same beds with other 
men, called the Shakers "filthy." His hostility towards the Shakers seems only to have deepened over time.

${ }^{35}$ See Rotundo, American Manhood: Transformations in Masculinity from the Revolution to the Modern Era (New York: Basic Books, 1993), 223. By the end of the nineteenth century, American men, obsessed with men's bodies including their own, "treated physical strength and strength of character" as the same thing.

${ }^{36}$ Wheeler Winston Dixon, It Looks at You: The Returned Gaze of Cinema (New York: State Univ. of New York Press, 1995), 2, 14, 17.

${ }^{37}$ Drawing on the work of sex researcher Theodor Reik, Silverman argues that "the male masochist," unlike the female, "leaves his social identity completely behind-actually abandons his 'self - and passes over into the 'enemy terrain' of femininity." Male masochism can be "disruptive," "shattering" (Male Subjectivity, 190). Though highly unpleasant for him, Coverdale's masochism does allow him to be critical of the masculine subject position as a whole and to empathize with women and female desire. On masochistic self-shattering, see Leo Barsani's Homos (Cambridge: Harvard Univ. Press, 1995).

${ }^{38}$ Nathaniel Hawthorne, "Circe's Palace," Hawthorne: Tales and Sketches (New York: Library of America, 1982) 1382-1408.

${ }^{39}$ On the implications of pigs as a beast-metaphor in Homer and elsewhere, see Marina Warner, No Go the Bogeyman: Scaring, Lulling, and Making Mock (New York: Farrar, Straus, and Giroux, 1998), 265-67, 277-78.

${ }^{40}$ Edelman's argument seems insensitive to the anguished awareness of racial inequality thoroughly saturating Du Bois's rhetoric, but I nevertheless find his depiction of the public performance of an enacted and wholly self-conscious masculinity useful. See Lee Edelman, Homographesis: Essays in Gay Literary and Cultural Theory (New York: Routledge, 1994), 50-51.

${ }^{41}$ Dixon, It Looks at You, 31.

${ }^{42}$ Rita K. Gollin discusses pigs in Hawthorne's work as signifiers of sensual decadence, "types of unmitigated sensuality." The figure of the pig can represent concupiscence in both men and women, female sexuality as well as male. But the strenuously specific nature of the gendered typing of the pigs in The Blithedale Romance should not be underestimated. "The Animal Department of Our Nature," The Nathaniel Hawthorne Review 30, nos. 1 and 2 (2004), 145-66.

${ }^{43}$ Creed's discussion of the monstrous-feminine-drawing, like Dixon, on the work of Kristeva-evokes "the dread of the generative mother seen only in the abyss, the monstrous vagina, the origin of all life threatening to reabsorb what it once birthed" (54). See Barbara Creed, The Monstrous-Feminine: Film, Feminism, Psychoanalysis (New York: Routledge, 1993). If in Lacanian terms the preSymbolic mother, associated with sounds, sensations, sights, and smells rather than language or rationality, represents the monstrous-feminine, the pigs in Hawthorne represent a pre-Symbolic father, animal and barbaric masculinity 
unvarnished by language, rationality, culture.

${ }^{44}$ The "whole of Richard III resonated" for the boy Hawthorne. See Brenda Wineapple's Hawthorne: A Life (New York: Knopf, 2003), 25-26. Wineapple links Hawthorne's fascination with the malformed Richard III to his ambivalent feelings about his maternal Manning family and his uncle Richard in particular.

${ }^{45}$ At the start of Marlowe's Edward II, the King's lover Gaveston, who has just been recalled from exile, names Actæon "by the angrie goddesse ... transformde" among the erotic entertainments he wants to stage for Edward in order to "draw the pliant king which way I please" (II:64-73). This homoerotic revision of the Diana-Actaeon myth correspond to Hawthorne's masculinization of the OdysseusCirce-male pigs episode from The Odyssey, and it also influences our reading of Hawthorne's own version of the Diana-Actaeon myth in The Blithedale Romance. Coverdale reproduces or is forced to relive his confrontation with the peeping pigs when he spies on the Comus-like masque of revelers in the forest. I thank Alan T. Bradford for reminding me of the Marlowe passage.

${ }^{46}$ Guy Hocquenghem's revolutionary Homosexual Desire (1972; Durham: Duke Univ. Press, 1993) discusses homosexual desire as "an arbitrarily frozen frame in an unbroken and polyvocal flux" (50). Hocquenghem's insistence that desire has multiple forms and cannot be subdivided into homosexuality or heterosexuality (i.e., imitative and prior forms) matches the polyamorous appreciation of male and female beauty in Hawthorne's work. Significantly for the pig-passage and its breakdown of normative forms of identity, as well as for Coverdale's inability to distinguish Westervelt from man or machine, Hocquenghem writes, "Homosexuality exists and does not exist, at one and the same time: indeed, its very mode of existence questions the again and again the certainty of existence" (53). The animal-male references - their interspecies blurriness-contribute to the overall sense of splintering, shaken order, dissolving reality.

${ }^{47}$ See Sacvan Bercovitch, The Office of The Scarlet Letter (Baltimore: Johns Hopkins Univ. Press, 1992), Jonathan Arac's "The Politics of The Scarlet Letter," in Ideology and Classic American Literature, ed. Sacvan Bercovitch and Myra Jehlen (New York: Cambridge Univ. Press, 1986), 247-66; and, for a contrasting reading, Larry J. Reynolds, "'Strangely Ajar with the Human Race': Hawthorne, Slavery, and the Question of Moral Responsibility," in Millicent Bell, ed., Hawthorne and the Real: Bicentennial Essays (Columbus: Ohio State Univ. Press, 2005), 64-65.

${ }^{48}$ Arac, 251, 254, 255, 256, 260. 